\title{
PRESIDENCIALISMO, GOVERNABILIDADE E OPOSIÇÕES PARLAMENTARES: uma análise crítica da literatura comparada
}

\author{
Paulo Peres* \\ Gabriella Bezerra **
}

\begin{abstract}
Nossa proposta neste artigo é analisar o debate teórico sobre o presidencialismo tendo como eixo central o tema da governabilidade e sua relação com a atuação das oposições partidárias na arena legislativa, brasileira e latinoamericana. Argumentamos que a preocupação com a consolidação das democracias recentes levou os analistas a privilegiarem a governabilidade em detrimento da efetividade da oposição parlamentar, demonstrando que a evolução dos estudos e dos debates acerca dos desenhos constitucionais mais adequados à consolidação democrática resultou, por um lado, na concepção de que, se forem efetivas, as oposições parlamentares podem prejudicar a consolidação das novas democracias e, por outro, num déficit de pesquisas empíricas sobre as suas prerrogativas e o seu comportamento. Defendemos a necessidade de superação desse viés normativo e do desenvolvimento de uma agenda de investigações sobre a sua atuação estratégica. Palavras-Chave: Oposições parlamentares. Presidencialismo. Governabilidade. Executivo e Legislativo.
\end{abstract}

\section{INTRODUÇÃO}

A governabilidade continua sendo uma das maiores preocupações dos analistas de política comparada considerando-se os estudos especializados das democracias da "terceira onda” (cf. Foweraker, 1998; Zelaznik, 2001; Ames, 2001; Weaver, 2002; Kooiman, 2008; Freeudenreich, 2016). De fato, tanto as reflexões teóricas, como as pesquisas empíricas desenvolvidas neste âmbito, tinham e ainda têm como meta a identificação do arranjo institucional mais adequado à promoção de uma relação cooperativa entre Executivo e Legislativo, evitando-se impasses que, muitas vezes, resul-

* Universidade Federal do Rio Grande do Sul (UFRGS). Departamento de Ciência Política.

Av. Bento Gonçalves, 9500 - Prédio 43322 (IFCH)/Sala 205. Bairro Agronomia. Cep: 91509900. Porto Alegre - Rio Grande do Sul - Brasil. peres.ps@gmail.com https://orcid.org/0000-0002-3880-4261

** Universidade Federal Rural de Pernambuco (UFRPE). Departamento de Ciências Sociais.

Rua Dom Manoel de Medeiros, s/n. Campus Dois Irmãos. Andar Térreo do Prédio Ariano Suassuna. Cep: 52171-900. Recife - Pernambuco - Brasil. gabriellamlb@gmail.com https://orcid.org/0000-0003-1420-5667

Agradecemos ao suporte financeiro da CAPES/CNPq ao projeto de pesquisa que resultou nesta análise. Somos igualmente gratos aos pareceristas pela avaliação criteriosa do artigo, assim como à Editoria da Revista pelo valioso espaço. tariam em crises que podem levar à interrupção do mandato presidencial pelo Parlamento (Pérez-Liñan, 2007, 2008, 2018; Marsteintredt; Berntzen, 2008; Llanos; Marsteintredt, 2010; Hochstetler, 2011; Kim, 2014; Lameira, 2019). Ainda assim, uma crise política pode se prolongar, ou aprofundar, a despeito do afastamento do Presidente, abrindo-se espaço para dois cenários mais traumáticos: a drástica ruptura do regime democrático por meio de algum golpe de Estado clássico, ou, então, a lenta erosão das instituições democráticas por meio da eleição de uma liderança populista (Levitski; Ziblat, 2018; Mounk, 2018; Pappas, 2019; Urbinati, 2019).

Desse modo, uma "engenharia constitucional” tornou-se prioritária nos estudos comparados das novas democracias (Sartori, 1997; Lijphart, 1992, 1994, 1996, 2003). Para diversos analistas, era imprescindível a identificação de arranjos institucionais que fossem imunes ou, ao menos, resistentes a possíveis retrocessos autoritários em decorrência de impasses instransponíveis entre o Executivo e o Legislativo (por exemplo: Linz, 1990a, 1990b, 1994, 2002; Shugart; Carey, 1992; Stepan; Skach 1993; Sar- 
tori, 1997; Lijphart, 1994; Mainwaring, 1993, 1999; Linz; Valenzuela, 1994a e 1994b, Jones, 1995; Lijphart; Waisman, 1996; Huber, 1996; Diamond, 1997; Mainwaring; Shugart, 1997a e 1997b; Tsebelis, 1995, 2002). Em ambos os casos - governabilidade difícil e ingovernabilidade com crise institucional - os especialistas preconizaram desenhos constitucionais que consideravam menos sujeitos à manifestação de múltiplos atores com poder de veto às políticas propostas pelo Executivo. Entendida como a capacidade do Executivo de aprovar sua agenda, sem maiores obstáculos interpostos pela oposição parlamentar (cf. Foweraker, 1998), a governabilidade legislativa foi associada tanto à eficiência como à qualidade da democracia sem a qual o próprio regime democrático estaria ameaçado. Em consequência disto, os analistas convergiram num ponto, qual seja, a governabilidade é a grande meta a ser atingida pelas novas democracias (cf. Ames, 2001; Amorim Neto, 2006).

Uma vez estabelecida essa concordância, os especialistas divergiram em relação aos fatores institucionais que produziriam efeitos deletérios sobre a governabilidade. Enquanto alguns deles alertavam para os perigos que a forma de governo presidencialista trazia à governabilidade (Linz 1990a; Linz;Valenzuela,1994a, 1994b;Valenzuela, 2004), outros chamavam atenção para o fato de que tais perigos somente existem no caso de se combinar mulจิ tipartidarismo com presidencialismo (Shugart; خ Carey, 1992; Mainwaring, 1993,1999). Mais \&े otimista, outro grupo de pesquisadores defen๘ dia que, a despeito das desconfianças iniciais, ลิ่ o presidencialismo de coalizão brasileiro de$\dot{2}$ monstrava que, tanto a forma de governo preळ sidencialista como o sistema multipartidário, não eram, necessariamente, obstáculos à governabilidade (Abranches, 1988; Figueiredo; Limongi, 1999, 2007; Santos, 2003; Amorim Neto, 2006, 2019; Limongi, 2008; Melo; Santos, 2013; Figueiredo, 2007; Luz; Aflalo; Dutra, 2018). Havia, portanto, uma solução institucional que permitiria alcançar elevada governabi- lidade em situações de extrema fragmentação partidária aliada a contextos de real separação entre os Poderes, tal como propiciado pelo sistema presidencialista (cf. Amorim Neto, 2006).

A proposta deste artigo é analisar este debate teórico sobre o arranjo institucional presidencialista no que se refere à sua capacidade de assegurar a governabilidade perante as oposições partidárias na arena legislativa. Como procuraremos mostrar, a preocupação com a governabilidade refletiu uma postura de cautela diante do potencial oposicionista para obliterar o governo e se envolveu em um dilema de difícil resolução. Se a efetividade das oposições parlamentares pode resultar na paralisia do governo, ou ao menos em governos acuados, meramente reativos, por outro lado, a governabilidade plena implica na nulidade dessas oposições. Diante desse paradoxo, a literatura temática foi levada a privilegiar a governabilidade em detrimento da oposição parlamentar, com base na premissa de que a consolidação das democracias recentes dependeria do predomínio do governo nas relações Executivo-Legislativo. Esse posicionamento ocasionou duas consequências: por um lado, tanto os estudos como os debates a respeito dos desenhos constitucionais impregnaram-se de um viés normativo desfavorável à atuação efetiva das oposições parlamentares; ${ }^{1}$ por outro, não se formou uma agenda de pesquisas voltadas ao exame das prerrogativas e do comportamento dessas oposições nas novas democracias (Morgenstern; Negri; Pérez-Liñan, 2008). Torna-se necessário, entretanto, a superação desse déficit, sobretudo no caso dos países da América Latina, onde a combinação da forma de governo presidencialista com o multipartidarismo tem implicações não apenas so-

\footnotetext{
${ }^{1}$ Por efetividade entendemos o desempenho eficaz de suas principais funções: (1) controlar/fiscalizar o governo, (2) influenciar/ retardar ou vetar projetos do governo. Isso depende das prerrogativas constitucionais e regimentais, mas também de sua força numérica e sua capacidade estratégica no processo legislativo. Essa efetividade, conforme discutiremos, enfrenta uma dificuldade que é ao mesmo tempo teórica e prática, referente ao que chamamos de paradoxo das oposições parlamentares em regimes demo-
} cráticos (Bezerra, 2017; Peres e Bezerra, 2020). 
bre a formação de governos de coalizão, mas também nas estratégias de coordenação das oposições parlamentares.

Ao analisar esta literatura, tendo tais enfoques e objetivo, pretendemos contribuir com o debate em dois aspectos. Primeiro, pretendemos mostrar como o percurso analítico nesta área de investigação resultou nessa lacuna e às reticências, tácitas ou explícitas, dos pesquisadores em relação às oposições parlamentares. Segundo, intentamos ressaltar a relevância do estudo das prerrogativas e do comportamento das oposições no processo de governo, pois, assim como a governabilidade, a efetividade das oposições parlamentares é indispensável ao regime democrático.

\section{A GOVERNABILIDADE E AS OPO- SIÇÕES NO PRESIDENCIALISMO}

A análise comparada das democracias recentes levou os pesquisadores à formação de um consenso acerca da relação negativa entre governabilidade e oposição partidária (por exemplo: Linz, 1990a, 1990b, 1994; Mainwaring, 1990; Geddes, 1991, 1996; Shugart; Carey, 1992; O’Donnell, 1992; Valenzuela, 1993; Mainwaring, 1993; Whitehead, 1996; Foweraker, 1998; Shugart, 1998). Com efeito, enquanto a governabilidade foi alçada à condição de máximo objetivo a ser garantido, a oposição partidária no Parlamento foi entendida como um potencial obstáculo à sua consecução. Obviamente, nem toda e qualquer oposição partidária foi percebida dessa maneira. Essencialmente, a oposição partidária ou a "contestação pública” pode se manifestar em duas arenas interligadas, porém, distintas - a eleitoral e a governamental (Verney, 1959). Sendo assim, podemos dizer que, na perspectiva da literatura temática, a atuação da oposição partidária na arena eleitoral garante a necessária competição pelo poder e, por isso mesmo, é um indicador de efetividade da democracia (Dahl, 1997). Em contrapartida, seria possível cogitar que uma oposição partidária eficaz na arena legislativa pode ser um entrave à governabilidade e, por extensão, uma ameaça à consolidação da democracia.

Sem dúvida, esse é um dilema de difícil resolução e, provavelmente, vem daí a reserva da literatura quanto à efetividade das oposições parlamentares. Com efeito, no âmbito desse debate a forma de governo presidencialista foi percebida como a mais propensa ao bloqueio das oposições partidárias no Legislativo; afinal, no presidencialismo não há nenhum instrumento regimental ou constitucional que permita uma saída institucional para impasses entre o Presidente e o Congresso (Linz, 1990 a, 1994; Shugart; Carey, 1992). Assim, se os parlamentares atuarem em oposição ao Executivo, a governabilidade será ameaçada e, obviamente, esse bloqueio depende de vários cenários, como a posição majoritária ou minoritária do governo no Parlamento, o tamanho e a coesão da coalizão de governo, os tipos de projetos em apreciação, o tamanho das maiorias exigidas para a aprovação dos projetos, os custos eleitorais dos projetos em deliberação, assim como das prerrogativas regimentais à disposição das oposições. E mais, se houver alta fragmentação partidária no Legislativo, a possibilidade de ocorrer tensões entre a oposição parlamentar e o Presidente eleva-se sensivelmente.

Já no parlamentarismo, em princípio, o governo é formado mediante a produção de uma maioria partidária no Congresso. No caso de regimes parlamentaristas bipartidários, o partido do chefe de governo será majoritário no Parlamento, assegurando-lhe alta governabilidade. Mas em sistemas multipartidários, o governo será formado depois de pactuada uma coalizão majoritária mais comprometida com a governabilidade. ${ }^{2}$ Impasses em situações como essas são extremamente difíceis e, se isso ocorrer, o Primeiro-Ministro poderá ser afastado por meio de uma moção de desconfiança dos

${ }^{2}$ Entretanto, cumpre-nos observar, governos minoritários em democracias multipartidárias não são incomuns e tampouco mais instáveis do que as majoritárias (cf. Strom, 1990). 
parlamentares, assim como o Primeiro-Ministro poderá dissolver o Congresso e chamar novas eleições legislativas (Linz, 1990b,1994; Shugart; Carey, 1992). Em contrapartida, como observa criticamente a literatura, os Presidentes não podem dissolver o Congresso e nem o Congresso pode emitir uma moção de desconfiança aos presidentes (Valenzuela, 1993; Mainwaring, 1993).

Com efeito, em decorrência do pessimismo dos especialistas em relação ao presidencialismo, por um lado, e à sua ampla adoção pelas novas democracias latino-americanas, por outro, a governabilidade veio a ser investigada pela ótica dos efeitos negativos dessa forma de governo no que se refere à construção de uma relação cooperativa entre Executivo e Legislativo (Cheibub; Limongi, 2002; Cheibub, 2006). Inevitavelmente, o presidencialismo acabou por se tornar um dos objetos mais estudados e debatidos no período posterior às transições democráticas - em realidade, discutir as novas democracias era discutir a dicotomia presidencialismo versus parlamentarismo, com a finalidade de se apontar as armadilhas do sistema presidencialista para a governabilidade (cf. Foweraker, 1998).

Historicamente, as reticências em relação ao presidencialismo têm suas raízes nos estudos sobre as transições democráticas dos anos 1980 e 1990. De maneira resumida, desde o final da Segunda Guerra já tinham se deธิ senvolvido três tipos de explicações para as N "falhas" da democracia no "terceiro mundo" \&̊ - socioeconômicas, culturais e institucionais. Em decorrência da chamada "revolução comสิ portamentalista”, as explicações estruturais, ¿. centradas em variáveis sociais e econômicas, ळ e, principalmente, as explicações culturalistas, $\overrightarrow{~ o f u s c a r a m ~ o s ~ e s t u d o s ~ d e ~ c a r a ́ t e r ~ i n s t i t u c i o n a-~}$ 苗 lista (cf. Peres, 2008). Porém, a "terceira onda democrática”, iniciada nos anos 1970, trouxe à tona a necessidade de se discutir com mais afinco os arranjos institucionais e seus efeitos políticos, afinal, os países que transitavam para a democracia tinham que lidar com a questão prática de desenhar suas constituições (Shugart; Carey, 1992; Foweraker, 1998).

Naquela altura, a motivação principal dos pesquisadores era avaliar as condições institucionais da forma de governo presidencialista para sustentar a consolidação da democracia nos países latino-americanos. Seu expoente mais notório e um dos principais responsáveis pelo retorno das instituições políticas consideradas como variáveis centrais no estudo das democracias foi Juan Linz. Preocupado com a identificação das variáveis que poderiam provocar falhas nas democracias recentes, Linz (1990a, 1990b e 1994) retomou uma dicotomia já tipificada anteriormente (Verney, 1959) para ressaltar os efeitos negativos do presidencialismo na governabilidade. Ele chamou atenção para duas características institucionais dessa forma de governo que considerava contraproducentes para a democracia: a legitimidade dual, que oporia o Executivo ao Legislativo, e o mandato fixo do Presidente. No primeiro caso, sendo cada poder totalmente independente um do outro, não haveria nenhum mecanismo institucional para a resolução de impasses, a não ser a disposição dos atores para a negociação, o que, para Linz, era algo muito incerto. No segundo caso, agravando esse problema, a rigidez do mandato fixo do Presidente não seria um fator de estabilidade como se pensava, mas sim de instabilidade, tanto em momentos de baixa popularidade do governo como em situações de crises insolúveis na sua relação com o Congresso. Dito de maneira mais direta, Presidentes impopulares e indesejáveis teriam que se arrastar até o fim do mandato, mesmo à custa de uma crise de governo e até da instabilidade institucional. Nesse caso, a gravidade da crise poderia levar a um golpe de Estado.

Nesse contexto, Linz estabeleceria toda uma agenda de pesquisa destinada a verificar se o presidencialismo de fato era uma ameaça à estabilidade das recentes democracias latino-americanas. Dessa forma, essa região assim como o Leste Europeu e a Europa Central - tornar-se-iam atraentes laboratórios para 
análises comparadas com esse escopo analítico. ${ }^{3}$ As investigações voltadas às recentes democracias tinham, portanto, um norteador normativo central, qual seja, buscar a eficiência institucional para se evitar as tensões e os possíveis impasses entre o Executivo e o Legislativo. Seguindo de perto as pegadas deixadas pela literatura sobre as transições democráticas, os analistas de orientação institucionalista deduziram que os desenhos constitucionais adotados, especialmente na América Latina, não ajudariam na consolidação do regime. Para eles, em virtude da herança histórica de um passado autoritário e da continuidade institucional de alguns elementos dos regimes ditatoriais no arranjo assumido pelas recentes democracias, esses países estavam sujeitos a retrocessos ou, no mínimo, a um desempenho de baixa qualidade (Mainwaring, 1990; Whitehead, 1996; Geddes,1996).

Acreditando não ter havido reais inovações nos desenhos constitucionais das novas democracias latino-americanas, alguns analistas concluíram que se tratava de modelos institucionais bastante homogêneos e propensos à crise. Essa homogeneidade constitucional se assentaria na forma de governo presidencialista - inclusive, a adesão da região ao presidencialismo teria limitado sobremaneira as escolhas institucionais nesses países e garantido, como efeito colateral, uma continuidade institucional importante do passado autoritário no novo ambiente democrático. Ou seja, tratou-se muito mais de se reestruturar as instituições adjacentes ao formato presidencialista já presentes nos governos autoritários, adaptando-as à democracia na medida do possível, do que propriamente de se desenhar instituições totalmente novas (Geddes, 1991; Linz, 1994; Shugart, 1998).

Para os autores comparativistas, um dos principais problemas a serem enfrentados por essas novas democracias era precisamente essa

${ }^{3}$ Nas palavras de Foweraker (1998, p. 651): "in particular, it created a new context for the study of the relationships between institutional design, party system and governability - defined in the narrow sense of institutional efficacy, as express through government stability, legislative capacity and the avoidance of gridlock". continuidade; afinal, uma coisa era a obtenção de governabilidade no presidencialismo, no caso dos regimes autoritários; outra coisa seria assegurar a governabilidade num ambiente democrático. Em regimes autoritários não há problemas de impasses entre Executivo e Legislativo, o que significa dizer que não há oposição efetiva - ou esta não é tolerada, ou é controlada rigidamente, ou, ainda, restringe-se a uma função apenas protocolar. Já nas democracias, supõe-se justamente que as oposições não apenas sejam toleradas, mas que tenham algum grau de efetividade. O problema, nesse caso, é que sua eficácia pode ser um obstáculo à governabilidade. Portanto, como lidar com essa diferença entre o presidencialismo autoritário (sem oposição efetiva) e o presidencialismo democrático (com oposição efetiva) quando a principal meta a ser buscada é a governabilidade?

De acordo com os analistas, em semelhantes situações haveriam apenas dois caminhos a trilhar: (1) ou a oposição legislativa não seria contornada pelo Executivo e as crises de governabilidade seriam frequentes, chegando, possivelmente, a provocar abalos institucionais (2); ou os Presidentes recorreriam a instrumentos autoritários, embora, constitucionalmente previstos, para sobrepujar o bloqueio legislativo. Neste último caso, no entanto, impor-se-ia uma dinâmica de governo baseada no "decretismo" (Shugart;Carey, 1992, Mainwaring, 1993; Geddes, 1996; Shugart,1998) e na “democracia delegativa” (O’Donnell, 1992). O problema disso é que, ao lançar mão de instrumentos executivos autoritários - tais como, no caso brasileiro, o uso recorrente de Medidas Provisórias, o abuso de iniciativas de legislação e a interferência recorrente na tramitação de projetos - para superação das crises de governo, o resultado seria, em primeiro lugar, a indevida subordinação dos parlamentares ao Executivo, com o consequente amesquinhamento do Congresso. E em segundo lugar, o potencial recrudescimento das tensões entre os Poderes, pois, os legisladores poderiam se unir para retaliar o Presidente em momentos críticos. 
Em síntese, em regimes democráticos, o presidencialismo provocaria uma oscilação dos governos entre o gridlock e o "decretismo"; entre os impasses do Presidente com o Congresso e o autoritarismo presidencial. No caso de um Legislativo forte, ou seja, com uma oposição majoritária e coesa, o cenário provável seria de impasses e crises institucionais; e no caso de um Executivo forte, o qual recorre a recursos de controle unilateral do processo decisório, a qualidade da democracia seria afetada por uma dinâmica autoritária de governo. Logo, golpes de Estado, autogolpes e funcionamento institucional precário com crises de governabilidade recorrentes permaneceriam como ameaças perenes às democracias latino-americanas. Portanto, se não plenamente violados, tais regimes democráticos seriam de baixa qualidade (O’Donnell, 1992; Mainwaring, 1993; Geddes, 1996; Shugart, 1998), uma vez que o presidencialismo padeceria de problemas endêmicos, como, por exemplo, a legitimidade dual que contrapõe o Parlamento ao Presidente em um contexto de interesses divergentes e até irreconciliáveis (Shugart; Carey, 1992).

\section{PRESIDENCIALISMO MULTIPAR- TIDÁRIO E GOVERNABILIDADE}

O desenvolvimento do debate inaugurado por Juan Linz levou os pesquisadores a le\&ิ vantarem uma série de questionamentos conF Ceituais e metodológicos às suas afirmações \% sobre a relação direta entre a forma de gover\& no e a governabilidade. Anteriormente, Riggs พิ๋ (1988) já havia alertado para a necessidade $\stackrel{2}{2}$ de se considerar os impactos de fatores "paraले constitucionais", como a cultura no funcionamento do presidencialismo. Na sequência, autores como Shugart e Carey (1992) e Mainwaring e Shugart (1997a,1997b) chamaram a atenção para um detalhe de suma importância até então não observado, qual seja, o presidencialismo, por si mesmo, não é um obstáculo à consolidação da democracia, ou mesmo à sua qualidade operacional, mas sim a variação do presidencialismo adotada na América Latina. Nessa região, de acordo com os autores, essa forma de governo foi combinada com dispositivos constitucionais que prejudicariam seu funcionamento. Em especial, eles chamaram a atenção para os efeitos "explosivos" da junção de presidencialismo com multipartidarismo (Mainwaring, 1990, 1993; Shugart; Carey, 1992; Jones, 1995; Ames, 2001). ${ }^{4}$

De modo geral, aqueles que se envolveram com essa agenda de pesquisas, conforme estabelecida por Juan Linz, conseguiram perceber três pontos relevantes. Em primeiro lugar, não há apenas um presidencialismo, mas uma variedade de modelos presidencialistas, cuja variação depende de sua combinação com outros fatores institucionais, como o sistema eleitoral, o sistema partidário, o arranjo federativo, as regras do processo legislativo e os poderes atribuídos ao Presidente. Em segundo lugar, a fragmentação partidária está diretamente associada à taxa de governabilidade - quanto maior a fragmentação, menor a governabilidade. Finalmente, em terceiro lugar, modelos presidencialistas multipartidários são os mais propensos a impasses e crises institucionais que somente podem ser superadas mediante a formação de coalizões de governo majoritárias. Porém, além de envolver custos de transação muito elevados, as coalizões só são realmente efetivas se contarem com alta taxa de disciplina parlamentar e elevada fidelidade dos partidos parceiros, algo que os analistas consideram difícil de ocorrer, especialmente em países com sistemas eleitorais que promovem o voto pessoal para o Parlamento e que estimulam o paroquialismo.

Ademais, de acordo com os comparativistas, as democracias presidencialistas latino-americanas via de regra elegem os seus

${ }^{4}$ Ressalta-se que a percepção pioneira dos efeitos da combinação de presidencialismo com multipartidarismo foi de Abranches (1988), ao analisar o caso brasileiro, para ele, sui-generis àquela altura. Ao apontar que essa combinação pode gerar problemas de governabilidade, entretanto, ressaltou que esse é o modelo mais indicado para a realidade complexa e heterogênea da sociedade brasileira. Daí o dilema institucional: é propenso à instabilidade, mas é o arranjo constitucional mais adequado ao Brasil. 
deputados pelo princípio de representação proporcional, o que é considerado um fator de instabilidade do presidencialismo na região, dado que essa fórmula estimula o multipartidarismo, um formato sistêmico "inimigo da democracia estável” (Mainwaring, 1990). Evidência disso seria o fato de que nenhuma democracia consolidada é presidencialista e multipartidária - com a exceção do Chile entre 1933 e 1973, todas as democracias presidencialistas que sobreviveram por pelo menos 25 anos eram bipartidárias ou tinham pouco mais de dois grandes partidos (Mainwaring, 1993). Podemos inferir que, aos olhos dos pesquisadores, o multipartidarismo cria impeditivos à formação de um governo majoritário porque o partido do Presidente dificilmente conquista a maioria das cadeiras parlamentares (Mainwaring, 1990, 1993; Jones, 1995; Ames, 2001; Sani; Satori, 1983). Consequentemente, o presidencialismo multipartidário não promove uma democracia de consenso, pois, com esse modelo, até mesmo a construção de uma coalizão majoritária é custosa e incerta (Mainwaring, 1990, 1993; Valenzuela, 1993).

Depreende-se disso, também, que o ponto nevrálgico aqui é a capacidade de o Executivo controlar a maioria parlamentar (Mainwaring, 1993; Mainwaring; Scully, 1995). Partindo-se da premissa de que quanto mais fragmentado o sistema partidário na arena legislativa, maior é a dificuldade de se obter a governabilidade, e admitindo-se que mesmo a formação de uma coalizão partidária majoritária, assim como a garantia de sua lealdade, é mais dispendiosa quando o número de parceiros é maior (Mainwaring, 1990, 1993, 1999; Sani; Sartori, 1983), então, a governabilidade depende consideravelmente do número de partidos com poder de veto no Parlamento, bem como da taxa de disciplina partidária. Adicione-se a isso o fato de que os governos minoritários, ou os governos que fazem coalizão majoritária com partidos indisciplinados, lidam, frequentemente, com ameaças de destituição dos seus Presidentes (Mainwaring, 1993; Jones, 1995;
Pérez-Liñan, 2007). Conclui-se daí que, num cenário de alta fragmentação partidária e personalismo parlamentar, a governabilidade é uma meta praticamente inalcançável.

Diante disso, para alguns pesquisadores, o ideal seria a combinação do presidencialismo com um sistema bipartidário. Para Mainwaring (1993), por exemplo, o bipartidarismo contribui para a moderação da competição, uma vez que sua dinâmica é centrípeta, levando à redução da polarização ideológica. Mas, em sendo inviável a prevalência do bipartidarismo, a segunda melhor alternativa seria criar um sistema de incentivos institucionais para a existência de um multipartidarismo moderado, com não mais do que três ou quatro partidos relevantes, já que os presidentes, forçosamente, têm que contar com um sistema de partidos com baixa fragmentação legislativa e alta disciplina dos parlamentares (Mainwaring, 1990, 1993; Stepan; Skach, 1993). ${ }^{5}$

Sendo assim, para a resolução dos dois problemas - fragmentação partidária elevada e baixa disciplina parlamentar - os analistas sugeriram que se investisse na alteração do sistema eleitoral (Mainwaring, 1993,1999; Ames, 1995a, 1995b, 2001; Jones, 1995; Samuels, 2003). Em realidade, segundo os pesquisadores, ao impactar a fragmentação partidária, o sistema eleitoral, indiretamente, produz efeitos sobre a capacidade do Executivo de formar coalizões majoritárias. A redução do número de partidos e o aumento do controle das organizações partidárias sobre os seus parlamentares, depende do abandono do voto em listas abertas, juntamente com a adoção de regras que funcionem como desincentivos à entrada de pequenos partidos no sistema, assim como a adoção de instrumentos partidários para a punição dos parlamentares indisciplinados. A representa-

${ }^{5}$ Curiosamente, Linz (1994) adverte para o contrário, ou seja, que em regimes presidencialistas multipartidários, o melhor é que os parlamentares sejam indisciplinados, pois somente assim o Presidente poderia negociar com cada um seu apoio em cada votação, recorrendo aos mecanismos de pork barrel e ao logrolling. Partidos disciplinados poderiam formar um bloco oposicionista ao governo de maneira inflexível, provocando uma crise institucional de difícil resolução dentro das regras do jogo democrático. 
ção majoritária em distritos pequenos, de preferência uninominais, associada a cláusulas de barreira à representação partidária e a uma série de desestímulos à criação de novas legendas poderiam resolver, ou ao menos minorar, o problema da fragmentação parlamentar. Aliado a isso, a realização de eleições concomitantes para a Presidência da República e o Parlamento contribuiria para a redução da fragmentação partidária no Legislativo (Jones, 1995). O voto em listas partidárias fechadas, por sua vez, daria aos partidos um maior poder de controle sobre o comportamento de suas bancadas, solucionando ou atenuando o problema da indisciplina nas votações em Plenário (Ames, 1995a, 1995b, 2001; Samuels, 2003).

Contudo, essa "solução ideal" para o presidencialismo latino-americano esbarrava em obstáculos sociais e operacionais não vislumbrados pela literatura. Em primeiro lugar, a quantidade de partidos não é uma função apenas das regras eleitorais, conforme já observado pelo próprio Duverger (1951) - e, de certo modo, admitido por Mainwaring (1993) . Há fatores sociais e históricos que também contribuem para a existência de muitos partidos (Amorim Neto; Cox, 1997; Ordeshook; Shvetsova, 1994); inclusive, em alguns casos, a própria heterogeneidade social exige o multipartidarismo (Abranches, 1988). Operacionalmente, tampouco seria factível supor que os partidos existentes num sistema possam vir ธิ a adotar regras eleitorais que reduzam drastii camente a quantidade de legendas, pois, eles

que, em sistemas partidários muito fragmentaลิ dos, como o brasileiro, as barreiras aos parti¿. dos serão mínimas e atingirão apenas os partiळ dos pequenos, deixando o mercado livre para

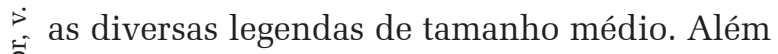
disso, mesmo que chegássemos a dois parti-

. ${ }^{6}$ Mainwaring (1993, p. 225) diz à certa altura: "the ad-

vantages of bipartism diminish where are sharp political

\} or social cleavages". De fato, como evidenciado por outros

$\supsetneq$ pesquisadores, o número de partidos de um sistema partidário depende da interação de variáveis institucionais, nomeadamente o sistema eleitoral, e de variáveis sociais (Amorim Neto; Cox, 1997; Ordeshook; Shvetsova, 1994). dos, o problema do impasse entre os Poderes no presidencialismo não seria completamente resolvido, pois, sempre haveria a possibilidade de existirem "governos divididos", que é quando um dos dois principais partidos controla o Executivo e o outro controla o Legislativo.

De fato, o problema do "governo dividido" veio à baila por causa de sua ocorrência na política norte-americana. Nos Estados Unidos, já houve situações como essa em vários momentos, dando ensejo a alguns impasses importantes entre a Casa Branca e o Congresso. ${ }^{7}$ Há, é claro, quem defenda que o "governo dividido" traz efeitos positivos porque garante a real separação entre os Poderes e, portanto, torna efetivo o processo de checks and balances. Isso porque, no caso do "governo unificado", ou seja, quando o mesmo partido controla o Executivo e o Legislativo, ocorreria uma espécie de junção virtual e temporária entre os Poderes, em moldes parecidos com o que acontece no modelo clássico do parlamentarismo inglês, como já apontado há tempos por Bagehot (1867).

Porém, há alguns aspectos que devem ser considerados mais detidamente. Ao contrário do modelo inglês, a Câmara Alta dos Estados Unidos tem muito mais poder, o que torna mais difícil uma situação de governo completamente unificado, caracterizado pelo controle da Presidência da República e o domínio simultâneo das duas casas legislativas pelo mesmo partido. Em desenhos constitucionais de real separação dos poderes - ou seja, o presidencialismo - e com um legislativo bicameral em que as duas Casas parlamentares têm poderes efetivos, a ocorrência de "governos divididos" em sistemas bipartidários pode ser mais frequente. Assim, conforme apontam seus críticos, ao invés de facilitar o checks and balances, os "governos divididos" podem levar a momentos de quase-paralisia do governo e a constantes gridlocks (Fiorina, 1992; Mayhew, 2005), pois o governo enfrentará uma oposição

\footnotetext{
${ }^{7}$ Nos Estados Unidos, houve muitos momentos de governo dividido, oscilaram de maneira pendular entre os dois partidos e os Republicanos são os que mais enfrentaram
} períodos de governo dividido. 
parlamentar majoritária e pouco afeita à cooperação. Portanto, se, por um lado, a dinâmica de "governo dividido" incentiva as negociações entre o Presidente e o Congresso em torno de compromissos programáticos básicos, por outro lado, dificulta consideravelmente a governabilidade (Moe, 1990).

Em realidade, situações de "governo dividido”, em regimes presidencialistas, podem levar a crises institucionais mais rapidamente do que nos casos de multipartidarismo. Em sistemas bipartidários, o partido que não conquista o Executivo, mas ocupa a maioria das cadeiras legislativas, terá todos os incentivos para atuar como uma oposição de bloqueio sistemático às políticas do governo, já que, agindo desse modo, aumentam as suas chances de conquistar a Presidência na próxima rodada eleitoral. Certamente, em casos como esses, a formação de uma coalizão é improvável. Portanto, se nos Estados Unidos as situações de "governo dividido" não resultaram numa grave crise institucional, não devemos descartar que isso talvez viesse a ocorrer de forma mais acentuada na América Latina, cuja tradição é de "oposição desleal", aquela que, em determinadas circunstâncias, força as regras do jogo democrático para além de seus limites constitucionais visando a chegar ao poder antecipadamente no próximo ciclo eleitoral - ilustrativos disso são os diversos golpes de Estado e, nos últimos anos, a elevada frequência de destituições constitucionais dos Presidentes da região. Portanto, há fundamentos empíricos para a suspeita de que "governos divididos" poderiam agravar ainda mais essa situação.

\section{SISTEMA ELEITORAL, MULTIPAR- TIDARISMO E GOVERNABILIDADE}

Para os analistas de política comparada, o problema da baixa governabilidade em regimes presidencialistas radica nas regras eleitorais, pois são elas as principais causadoras da proliferação de partidos e, ainda, da in- disciplina parlamentar (cf. Mainwaring, 1990, 1993, 1999; Ames, 1995a, 1995b, 2001). Esse modelo explicativo, por consequência, coloca o sistema eleitoral no centro do debate acerca da instabilidade institucional das novas democracias latino-americanas. Como é sabido, pelo menos desde a obra mais reconhecida de Duverger (1951), as formas de escrutínio influenciam a quantidade de partidos de um sistema; do mesmo modo, o voto em listas partidárias abertas, sujeitas à interferência dos eleitores na ordem dos eleitos, foi associado ao tipo de comportamento que o parlamentar adota no processo legislativo, se mais paroquial ou mais universalista (Mayhew, 1974; Ames, 1995a, 1995b, 2001). Por isso, o sistema eleitoral foi alçado à condição de variável explicativa das falhas do presidencialismo e, assim, seus efeitos sobre o formato do sistema partidário e o comportamento parlamentar foram considerados os responsáveis por diferenciar as democracias presidencialistas estáveis daquelas sujeitas a crises constantes (Mainwaring, 1990, 1993).

Com base nessa concepção, a literatura temática inferiu que a fórmula de representação proporcional era a indutora do multipartidarismo (Shugart; Carey,1992; Mainwaring; Shugart, 1997a, 1997b) e, portanto, da baixa governabilidade. Claro que, no caso de países nos quais se considerou haver uma larga permissividade à criação de novos partidos, outros aspectos da legislação eleitoral e da legislação partidária foram incluídos no rol de fatores de estímulo à fragmentação excessiva do sistema partidário - quanto ao modelo brasileiro, por exemplo, o voto nominal em listas abertas foi identificado como um incentivador da competição entre os candidatos da mesma legenda, assim como da ligação paroquialista entre políticos e eleitores (Jones, 1995; Ames, 1995a, 1995b, 2001; Samuels, 2003). Além disso, essa forma de escrutínio levaria os Deputados a se comportarem de maneira individualista no Legislativo, incrementando ainda mais o problema da fragmentação parlamentar. O voto em listas abertas atuaria, enfim, como uma força 
contrária à coesão e à disciplina dos partidos.

Sob a rubrica de "conexão eleitoral", postulou-se, então, a influência direta do sistema eleitoral sobre o comportamento clientelista dos eleitores e, principalmente, sobre o comportamento parlamentar antipartidário. Não é por menos que esses analistas identificaram o Brasil como o país com o sistema partidário mais fragmentado do mundo e menos institucionalizado da região (Mainwaring, 1995,1999; Mainwaring; Scully, 1995), e onde os parlamentares atuariam orientados pela política do pork barrel (Ames, 1995a, 1995b; Pereira; Rennó, 2001,2007; Carvalho, 2003; Samuels, 2003). Desse modo, a circularidade do argumento atinge a meta normativa a ser perseguida - mediante os incentivos dados por essa estrutura institucional, a governabilidade seria gravemente comprometida, senão impossível.

Não obstante, a evolução desse debate centrado no Brasil acabou provocando uma inflexão na literatura. Pesquisas posteriores, concentradas apenas no caso brasileiro, contribuíram para dissipar ou pelo menos relativizar muitas das suspeitas em relação à viabilidade do presidencialismo multipartidário. Alguns pesquisadores brasileiros reuniram dados empíricos surpreendentes sobre o grau de disciplina dos partidos nas votações em plenário e a taxa de governabilidade dos presidentes no país. Seus estudos mostraram que, apesar da fragmentação partidária no Legislaసิ tivo, os Presidentes formavam coalizões majo† ritárias, os parlamentares votavam de acordo \&̊ com a orientação de suas lideranças e, assim, \& a governabilidade era elevada (Figueiredo; Liงิ mongi, 1999; Meneguello,1998; Amorim Neto, 2. 2006; Melo; Pereira, 2013).Dessa maneira, de ळ acordo com esses estudos, a centralização do

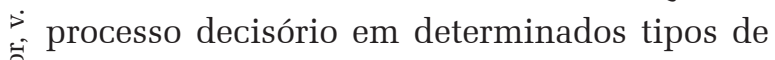
presidencialismo, garantida por aspectos institucionais até então não contemplados pelos analistas de política comparada, como os regimentos internos das Casas Legislativas, assegurava, simultaneamente, maior eficiência administrativa e menor instabilidade política
(Figueiredo; Limongi, 1999; Santos, 2003). ${ }^{8} \mathrm{Ou}$ seja, a dinâmica da política institucional brasileira indicava que, conforme já havia sido caracterizado por Abranches (1988), era possível um presidencialismo de coalizão. ${ }^{9}$

É claro que esse otimismo com o presidencialismo de coalizão e seus assemelhados foi sensivelmente abalado pelos frequentes episódios de instabilidade política e interrupções de mandatos presidenciais na América Latina (Valenzuela, 2004). Não obstante, análises mais aprofundadas desses episódios dão conta de que os afastamentos dos Presidentes na região demonstram que as reservas de Juan Linz e tantos outros em relação aos efeitos negativos da rigidez temporal do mandato presidencial sobre a estabilidade institucional não se confirmaram, pois, nos momentos de crises política, os mandatos fixos dos Presidentes não provocaram retrocesso autoritário (Pérez-Liñan, 2007; Marsteintredet; Berntzen, 2008; Llanos; Marsteintredet, 2010; Marsteintredet, 2014). Na verdade, ainda de acordo com os especialistas, as pressões dos protestos populares e seu acolhimento pelo Legislativo, cujos resultados muitas vezes foram interrupções de mandatos presidenciais, seja por renúncia ou por processos de impeachment, são indicativos tanto do fortalecimento da "democracia das ruas" como da maleabilidade institucional do presidencialismo em episódios de impasse entre os Poderes. Em suma, as tensões irreconciliáveis entre os Presidentes e os Parlamentos, assim como entre os Presidentes e a população, não são mais resolvidas por golpes de Estado, mas por procedimentos previstos nas Constituições (Pérez-Liñan, 2007). ${ }^{8}$ Os livros de Figueiredo e Limongi (1999) e Santos (2003)
são coletâneas de diversos artigos publicados em revistas
científicas desde meados dos anos 1990 , contendo resul-
tados de suas pesquisas que traziam achados empíricos
sobre a elevada governabilidade, a alta taxa de disciplina
partidária e o processo de racionalização do processo le-
gislativo brasileiro.
9 Sobre isso, Melo e Pereira (2013, p. 01-02) chegaram a
declarar que "the association between multiparty presiden-
tialism and sustainable democracy is now beyond dispute
(...). (...) Chile and Brazil have emerged as the successful
models for governance in the Latin American region. And
both countries are multiparty presidential democracies
whose presidents are among the strongest in the region". 
Não cabe explorar aqui pontos contraditórios e polêmicos desses argumentos, mas é importante destacar que, no mínimo, é controversa a alegação de que as interrupções dos mandatos presidenciais são evidências de fortalecimento da democracia participativa, por intermédio das pressões populares nos protestos de rua, cujo resultado é o afastamento dos chefes do Executivo. Tampouco é isenta de controvérsias a alegação de que o uso do impeachment como um instrumento de flexibilização da rigidez temporal do mandato presidencial para a solução de problemas de governabilidade, mediante a remoção do chefe do Executivo, seja um mecanismo semelhante ao voto de desconfiança do parlamentarismo. Em princípio, recorrer ao dispositivo do impeachment como uma moção de desconfiança ao Presidente para removê-lo do cargo contribui para solapar as bases institucionais da forma de governo presidencialista. Esta é uma observação estritamente institucional, pois, além de nem sempre resolver satisfatoriamente as crises políticas, que podem se prolongar ou até se aprofundar, o impeachment como moção de desconfiança atribui ao Legislativo o poder de cassar um mandato atribuído pelo voto popular.

Seja como for, o que é mais relevante dessa discussão é que, por detrás de todo esse debate, e até das divergências entre os pesquisadores, permanece um consenso bastante nítido quanto àquela que é a maior preocupação de fundo: qual o desenho constitucional mais indicado para a obtenção de governabilidade elevada? Nesse contexto, a governabilidade mesma é identificada com a agenda do Poder Executivo, enquanto as oposições parlamentares são percebidas como um entrave à implementação dessa agenda.

\section{CONTRADIÇÕES DA LITERATURA COMPARADA EM RELAÇÃO ÀS OPOSIÇÕES}

Apesar de realmente ser indispensável ao bom funcionamento da democracia, a go- vernabilidade é apenas uma parte do processo de governação em regimes democráticos. A desatenção em relação a esse ponto, em favor de uma acentuada preocupação com a governabilidade, teve como resultado um hiato empírico e uma contradição conceitual na literatura temática. Além das oposições parlamentares não figurarem nas agendas de pesquisa dos especialistas como um objeto de investigação principal, sua potencial atuação de maneira mais efetiva acabou sendo percebida, mesmo que indiretamente, como um entrave ao bom funcionamento do regime democrático. Isso porque, como já salientado, sua capacidade de vetar as políticas do Executivo veio a ser considerada nociva à governabilidade.

Destarte, as oposições partidárias acabaram sendo percebidas como veto-players capazes de produzir crises institucionais e, se detiverem poder excessivo, hábeis para produzir situações de "quebra" da democracia. A lógica desse raciocínio assentou-se na concepção de que se o regime democrático dá poder à vontade da maioria, e se o governo é uma coalizão partidária que controla o Executivo e a maior parcela das cadeiras do Legislativo, então, a oposição ao governo deveria ser praticamente protocolar, pois, em caso contrário, constituir-se-ia numa barreira interposta pela minoria ao governo. No caso de a oposição parlamentar ser majoritária, o problema seria ainda mais grave, uma vez que o governo ver-se-ia completamente bloqueado no processo legislativo, correndo o risco de até ser destituído em virtude de processos de impeachment, ou outros expedientes previstos constitucionalmente para seu afastamento, como também já ressaltado.

Daí resulta a contradição, ou seja, ao mesmo tempo em que a literatura adota a concepção de democracia de Robert Dahl (1997), transparece nessas análises a noção de que a oposição é um ator político secundário e perigoso, pois é um potencial obstáculo à consolidação do regime, ou, no mínimo, é capaz de comprometer a sua qualidade. É como se a consolidação da democracia dependesse mais 
diretamente da governabilidade por intermédio do protagonismo do Executivo do que dos controles exercidos sobre o governo pelas oposições parlamentares - por isso, atribui-se ao Poder Executivo um grau de importância muito maior do que à efetividade das oposições no Legislativo. Em realidade, é como se as oposições se predispusessem a colocar vetos indesejáveis à agenda governista sempre que tivessem a possibilidade de desempenhar de maneira efetiva as suas funções; é como se governo fosse sinônimo de Poder Executivo e seus projetos fossem a expressão imediata da vontade popular majoritária. Haveria, assim, um trade-off democrático a ser manejado a favor do Executivo: para que o governo seja mais efetivo, a oposição deve ser menos efetiva.

Dessa forma, podemos extrair desse debate o seguinte posicionamento da literatura no que diz respeito ao status que a oposição tem ou deve ter, de acordo com o regime. Em governos autoritários, a oposição partidária ou inexiste ou é controlada - quando o regime autoritário é bastante rígido e não tem qualquer pretensão de exibir uma fachada democrática, os opositores não são admitidos em nenhum canal institucional de atuação; eles são combatidos em todas as instâncias da vida social. Quando o regime autoritário é menos rígido - ou mesmo quando é consideravelmente rígido e tenta parecer minimamente democrático ou sinalizar que se trata de uma intervenção momentânea - algum จิ nível de oposição será permitido, inclusive se-

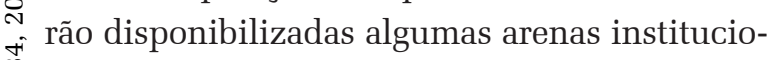
\&̊ nais para a sua contraposição ao governo. Po¿ rém, tratar-se-á de uma oposição controlada por ลิ diversos expedientes, até mesmo pela manipu-

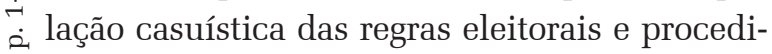
ळ mentais do Legislativo - o regime autoritário de 1964 brasileiro é um exemplo disso.

Já no caso de regimes democráticos, podemos identificar uma posição contraditória da literatura especializada mencionada há pouco. Cerrando fileiras com os critérios propostos por Dahl (1997), os analistas consideram que um dos aspectos cruciais para a identificação de uma democracia é a tolerância às oposições. Não obstante, do ponto de vista de sua atuação efetiva, há uma disparidade quando consideramos as arenas eleitoral e legislativa. Espera-se que as oposições partidárias sejam bastante eficazes na arena eleitoral, garantindo a necessária competição pelo governo. Todavia, na arena legislativa, as oposições partidárias devem ser protocolares. Isso quer dizer que elas devem cumprir sua função de propor alternativas, de fazer denúncias e fiscalizar o governo, mas não é desejável que as oposições parlamentares se tornem eficazes enquanto atores de veto à agenda do Executivo. Obviamente, em casos assim, também não é desejável que a oposição parlamentar seja majoritária e coesa.

De fato, esse descompasso já está presente na própria teoria de Dahl, que assevera que:

quando regimes hegemônicos e oligarquias competitivas se deslocam na direção de uma poliarquia, eles aumentam as oportunidades de efetiva participação e contestação e, portanto, o número de indivíduos, grupos e interesses cujas preferências devem ser levadas em consideração nas decisões políticas (Dahl, 1997, p. 36).

Isso significa que, ainda de acordo com o autor,

(...)quanto maior o conflito entre governo e oposição, mais provável é o esforço de cada parte para negar uma efetiva oportunidade de participação à outra nas decisões políticas. Em outras palavras, quanto maior o conflito entre o governo e seus oponentes, mais difícil se faz a tolerância de cada um para com o outro (Idem, p.36).

Devido a isso, Dahl sugere que os custos de eliminação da oposição devem ser maiores do que os custos de sua tolerância, e que tais custos seriam impostos por algum dispositivo da estrutura institucional democrática.

Não obstante, dois problemas permanecem. Em primeiro lugar, o autor não dá atenção à necessidade de que a oposição também tolere o governo, algo que se tornou crucial na América Latina depois da redemocratização, 
como ilustram os inúmeros casos de pedidos de impeachment e de perdas de mandatos presidenciais. Em segundo lugar, o que é mais relevante para a presente discussão, Dahl (1997) parece resguardar para a oposição partidária apenas o espaço para o exercício da contestação pública nos processos eleitorais, deixando a descoberto outra arena igualmente importante de atuação, a legislativa. Ao não salientar a necessidade de tolerância às oposições na arena parlamentar, e mais, a necessidade de que estas sejam efetivas no Legislativo, a identificação dos regimes democráticos pelos seus critérios considera apenas a existência de competição partidária nas eleições, que devem se caracterizar por ampla inclusão eleitoral. O resultado disso, vale a pena reforçar, foi a despreocupação com o estudo das oposições partidárias parlamentares e com a sua efetividade.

Indubitavelmente, esse foi um desenvolvimento inusitado para os estudos comparados dos regimes democráticos. Nos anos 1970 e 1980, quando o debate girava em torno das transições dos regimes autoritários para a democracia, os pesquisadores se mostraram amplamente receptivos à atuação das oposições políticas, inclusive no Parlamento, como é o caso do Brasil. A perspectiva predominante naquela altura era a de que a tolerância às oposições seria um indicador de transição para a democracia, e a própria democracia aprofundar-se-ia à medida que as oposições, principalmente as partidárias, lograssem êxito na contestação ao governo e na competição eleitoral, resultando na rotatividade dos grupos políticos no poder. A partir dos anos 1990, porém, já motivados pelo debate acerca da consolidação democrática e sua relação com os desenhos constitucionais, os comparativistas mudaram sensivelmente de perspectiva em relação às oposições parlamentares. Desde então, estas foram percebidas como potencial ameaça à estabilidade política - nesse sentido, enquanto nas ditaduras a instabilidade seria positiva porque representaria a possibilidade de superação desse regime, nas democracias, a insta- bilidade abriria espaço para crises e possíveis golpes de Estado.

De acordo com essa perspectiva, a consolidação democrática dependia da capacidade de o desenho constitucional incentivar a coordenação de partidos e indivíduos em torno de uma vontade majoritária intransponível, expressa por uma coalizão de governo coesa (Shugart; Carey, 1992; Lijphart, 1992; Linz; Stepan, 1993; Sartori, 1997; Mainwaring; Shugart, 1997; Cheibub, 2006; Amorim Neto, 2006). Com esse enquadramento, tanto teórico como normativo, os sistemas presidencialistas da América Latina foram escrutinados a fim de se determinar o grau de descentralização dos seus arranjos federativos, dos seus sistemas eleitorais, das suas organizações partidárias e das relações entre os Poderes Executivo e Legislativo (Kitschelt et al., 2010; Amorim Neto, 2006; Haggopian; Mainwaring, 2005; Gibson, 2004; Morgenstern; Nacif, 2002; Coppedge, 1998; Mainwaring; Shugart, 1997; Mainwaring; Scully, 1995; Linz; Valenzuela, 1994; Stepan; Skach, 1993; Linz 1990a, 1990b, 1994).

No âmbito desse debate, era mesmo de se esperar que surgissem poucos estudos sobre as oposições parlamentares. Até mais do que isso, era de se esperar que as oposições parlamentares fossem vistas com desconfianças. Agregue-se aqui, ainda, o fato de que, desde há muito tempo, difundiu-se uma perspectiva bastante favorável ao parlamentarismo, cujas principais qualidades sempre foram exaltadas (Linz, 1990a, 1990b e 1994; Linz; Valenzuela, 1994a e 1994b; Stepan; Skach, 1993). Dentre elas, a principal seria a fusão institucionalmente prevista entre Executivo e Legislativo para a formação do governo e, com isso, a suposta existência de uma oposição não-disruptiva. Agregue-se a isso, por fim, as dificuldades de os governos presidencialistas atingirem taxas mais elevadas de sobrevivência a longo prazo (cf. Lijphart, 1992; Mainwaring, 1993; Stepan; Skach, 1993; Przeworski et al., 2000). ${ }^{10}$

${ }^{10}$ Esses dados e essa conclusão são contestados por Cheibub (2006). Para ele, a taxa de sobrevivência do presiden- 
GOVERNABILIDADE E DEMOCRACIA NA LITERATURA SOBRE O BRASIL

O debate sobre as condições constitucionais de obtenção de governabilidade, protagonizado pelos analistas de política comparada, chegou ao contexto brasileiro de duas maneiras. A primeira foi por meio das análises do presidencialismo na América Latina, nas quais o Brasil muitas vezes estava incluso e costumava ser identificado como o caso exemplar de uma péssima escolha constitucional - presidencialismo com multipartidarismo e arranjo federativo (Mainwaring, 1990, 1993; 1999; Abrúcio 1998; Ames, 2001). Com um dos arcabouços institucionais mais fragmentados da região, a política brasileira abrigaria muitos atores com poder de veto e estaria sujeita a crises intermitentes de governabilidade. A segunda maneira foi por intermédio do impacto que o debate dessa literatura provocou na agenda de pesquisa de cientistas políticos brasileiros a partir de meados dos anos 1990. Esse debate deu impulso aos estudos legislativos no país, cujos achados reverteram as afirmações da literatura comparativa e trouxeram elementos para se pensar em outros termos o problema da governabilidade em regimes presidencialistas (Figueiredo; Limongi, 1999, 2000; Santos, 2003; Amorim Neto, 2006; Melo; Pereira, 2013). ${ }^{11}$

Com efeito, desde o surgimento dos estudos legislativos no país, o debate sobre a deసิ † parâmetro a dicotomia presidencialismo/parlamentarismo (Miranda 2009, 2010; Cheibub et al., 2004; Freitas, 2016). No centro do debate, N uma disputa teórica e empírica sobre a viabili$\dot{\dot{2}}$ dade do nosso modelo. De uma parte, pesqui-

cialismo é uma medida enviesada porque a instabilidade desse regime não se deve propriamente ao seu desenho

ఫิ institucional, mas sim à instabilidade política da América

Z Latina. Quando se compara os regimes, tem-se esse resul-

$\geqslant$ tado desfavorável à forma de governo presidencialista. In-

i fere-se daí que regimes parlamentaristas seriam igualmenTe ou mais instáveis na região.

11 Para uma análise crítica dessa literatura, ver Peres e Carvalho (2012) e Peres (2014). Para uma discussão mais recente sobre a evolução das relações entre Executivo e Legislativo no presidencialismo de coalizão brasileiro, conferir: Santos e Perlin (2019), Dantas (2018), Freitas (2016). sadores mais pessimistas subdividiram-se em dois grupos. O primeiro deles considerava que o Poder Executivo manteve resíduos autoritários do regime ditatorial, pois o atual modelo constitucional o equipou com prerrogativas excessivas, como as medidas provisórias e o controle do orçamento (Geddes, 1991; Shugart; Carey 1992; O’Donnell,1992); assim, o Legislativo ver-se-ia na condição de um Poder submisso ao Executivo (cf. Foweraker, 1998). Já o segundo grupo defendia a posição de que, a despeito dos poderes conferidos ao Presidente, o Legislativo detêm prerrogativas constitucionais que o permitem controlar e limitar as ações do Chefe do Executivo, que muitas vezes enfrenta sérias dificuldades para aprovar sua agenda (Mainwaring, 1990; Jones, 1995; Ames, 2001).

Para os filiados a esta última perspectiva, por ser tão poderoso, o Legislativo pode representar uma ameaça à governabilidade, especialmente quando há multipartidarismo. Isso porque, em seus traços fundamentais, o desenho institucional de 1988 reproduziu a mesma lógica fragmentadora do modelo de 1946 - federalismo, representação proporcional, multipartidarismo e presidencialismo (Mainwaring, 1993; 1995, 1997, 1999; Mainwaring; Pérez-Liñan, 1997; Abrúcio, 1998; Ames, 2001; Samuels, 2003). Ademais, esse arranjo geraria incentivos para a prevalência do personalismo eleitoral e a consequente falta de coesão partidária num cenário de elevada fragmentação parlamentar, fatores que inviabilizam a construção de maiorias legislativas para garantir a governabilidade. Portanto, assim como no período de 1946-64, a democracia atual estaria propensa a crises de "paralisia decisória" (Santos, 1986).

De outra parte, pesquisadores de uma geração mais recente se mostram mais otimistas e defenderam que o presidencialismo de coalizão é capaz de assegurar uma taxa de governabilidade satisfatória e, assim, a estabilidade institucional. De fato, essa literatura trouxe evidências de que o Presidente da República dispõe de diversos recursos para incentivar 
a colaboração dos partidos por meio de coalizões estáveis e coesas (Abranches, 1988; Figueiredo; Limongi, 1999; Limongi; Figueiredo, 2008; Santos, 2003; Inácio; Rennó, 2009; Melo; Pereira, 2013). ${ }^{12}$ Tais trabalhos mostraram que duas dimensões institucionais favoreciam a centralização das decisões no Parlamento - os poderes legislativos do Presidente e as regras do processo decisório na Câmara dos Deputados. Além dos instrumentos institucionais que permitem o controle da agenda legislativa e a interferência na tramitação de projetos, o Executivo detém a prerrogativa de elaborar a peça orçamentária e de liberar emendas parlamentares ao orçamento, assim como inúmeros cargos para serem distribuídos aos aliados, incluindo-se as pastas ministeriais.

Em linhas gerais, os autores colocaram em relevo o que chamaram de bases institucionais do presidencialismo de coalizão brasileiro (cf. Figueiredo; Limongi, 1999) - um modelo que, para eles, contêm um sistema de incentivos capaz de fazer do Poder Executivo uma força gravitacional irresistível, atraindo, assim, os partidos para sua base de apoio no Legislativo. ${ }^{13} \mathrm{O}$ processo decisório, centralizado na Presidência da República e nas lideranças partidárias, seria então alimentado com uma série de prerrogativas institucionais inovadoras trazidas pela Constituição de 1988, aliada à continuidade de dispositivos oriundos do período autoritário, nomeadamente, as medidas provisórias. Somam-se a isso os dispositivos dos regimentos internos da Câmara dos Deputados e do Senado que auxiliam as lideranças partidárias na coordenação das suas respectivas bancadas.

Sem dúvida, a sequência de estudos

${ }^{12}$ Para uma revisão crítica dessa literatura, consultar Palermo (2000) e Peres e Carvalho (2012).

${ }^{13}$ Em texto posterior, Limongi (2006) voltou à discussão do conceito de presidencialismo de coalizão, à luz dos estudos legislativos desenvolvidos a partir de meados dos anos 1990. Mais recentemente, Figueiredo e Limongi (2017) voltaram a esse debate para tentar explicar a crise política brasileira que levou ao impeachment da presidenta Dilma Rousseff, mantendo-se a validade teórica e prática do modelo de governo denominado presidencialismo de coalizão. empíricos de Figueiredo e Limongi (1999) daria início à agenda dos estudos legislativos revisionistas, considerada mais otimista em relação às perspectivas anteriores, inclusive, do próprio formulador da expressão "presidencialismo de coalizão", o cientista político Sérgio Abranches. Para este, ainda no contexto da produção da Carta Constitucional, o Brasil teria de enfrentar um dilema institucional, caracterizado “(...) pela necessidade de se encontrar um ordenamento institucional suficientemente eficiente para agregar e processar as pressões derivadas do quadro heterogêneo [do país, em] bases mais sólidas para sua legitimidade”. Um modelo que, continua o autor, “(...) o capacite a intervir de forma mais eficaz na redução das disparidades e na integração da ordem social" (Abranches, 1988, p. 7-8).

Reconhecendo que o arranjo institucional atual reflete a estruturação histórica bastante complexa e plural da sociedade brasileira, Abranches (1988) defendeu a ideia de que tentar impor a representação majoritária para a alocação das cadeiras legislativas, a fim de se reduzir o número de partidos, seria uma artificialidade prejudicial que não resolveria o nosso dilema institucional. Em sua perspectiva, nosso desenho constitucional foi a solução mais adequada para se articular a pluralidade de interesses com as demandas sociais, expressas no sistema multipartidário; ao mesmo tempo, porém, isso significa que temos que produzir uma maioria governativa capaz de evitar a obstrução da agenda do governo pelas oposições parlamentares. O problema da formação de maioria, por sua vez, agrava-se com a crescente fragmentação do sistema partidário, pois isso obriga o Executivo a formar coalizões muito amplas, inclusive acima da mínima maioria necessária para aprovar os seus projetos. Isso ocorre porque, segundo ele, as coalizões devem acomodar não apenas os partidos, mas também grupos políticos regionais suprapartidários. ${ }^{14}$

${ }^{14}$ Sobre a formação de maiorias acima do mínimo necessário no Brasil e também nos outros países da América Latina, ver Meireles (2016). 
O problema mais grave dessa dinâmica é que, além de se ampliar demais a diversidade ideológica da coalizão, dificultando a implementação de uma agenda política coerente, a própria administração dessa aliança adquire, cada vez mais, custos proibitivos, do mesmo modo que a distribuição de cargos e recursos sempre gerará insatisfações entre os parceiros. ${ }^{15}$ Além disso, é provável que surja alguma oposição parlamentar de dentro da própria base partidária do governo (Hiroi, 2013). Por isso, ao mesmo tempo em que as coalizões são necessárias para expressar acordos e negociações dos diversos interesses e demandas do país, elas são o comburente da explosão prevista para o presidencialismo multipartidário.

Este é, portanto, o dilema institucional brasileiro: precisamos de um sistema político fragmentado (presidencialismo multipartidário), mas isso demanda coalizões de governo (presidencialismo de coalizão) que, no geral, são instáveis. ${ }^{16}$ Rejeitando o parlamentarismo e o bipartidarismo como solução, Abranches (1988) conclui sua análise ressaltando que o desafio consiste em dotar o presidencialismo de coalizão de mecanismos institucionais que favoreçam a regulação do conflito partidário dentro da base de apoio ao governo, com a finalidade de se evitar que ela se esgarce e atinja o Presidente, e, ao mesmo tempo, que possibilite a regulação mais estável da diversidade de demandas sociais em relação ao governo. governo e, assim, a estabilidade e a fidelidade da coalizão. Desse modo, as reivindicações de Sérgio Abranches para a superação do que ele chamou de "dilema institucional brasileiro" teriam sido atendidas na nova Carta Constitucional. Até mais do que isso, os poderes agora atribuídos ao Presidente asseguraram ao Executivo a posição de preponderância em relação ao Legislativo. Por consequência, a governabilidade seria assegurada pelos incentivos do arranjo institucional à cooperação entre o Presidente e o Congresso. ${ }^{17}$

Certamente, desse debate saíram valiosas contribuições. Os estudos legislativos brasileiros, desenvolvidos a partir de meados dos anos 1990, aportaram à agenda dessas pesquisas uma perspectiva mais empírica, análoga à desenvolvida no contexto norte-americano. Esses estudos, ademais, trouxeram importantes contribuições teóricas ao debate constitucionalista ao adotar uma abordagem neoinstitucional que que demostrou que o presidencialismo e o parlamentarismo podem operar de maneira semelhante em certos aspectos. Contribuíram, também, ao mostrar que o embate político central não é simplesmente entre o Executivo e o Legislativo, mas entre o governo e a oposição, uma vez que o governo abrange partidos que estão tanto no Executivo como no Legislativo. E, ainda, inovaram ao salientar que não apenas o sistema eleitoral e a forma de governo influenciam a governabilidade, mas também o grau de centralização do processo legislativo estabelecido pelas regras internas do Congresso e pelos poderes legislativos atribuídos ao Presidente (cf. Power, 2009, 2010). ${ }^{18}$ Entretanto, a polêmica envolvendo essa

17 “(...) o Poder Executivo, em virtude de seus poderes legislativos, comanda o processo legislativo (...). (...) O resultado é a atrofia do próprio Legislativo e a predominância do Executivo(...). Assim, a hipótese segundo a qual o Legislativo se constitui em obstáculo à ação do Executivo não encontra apoio, quer se olhe para o quadro legal, quer se olhe para a produção legal. (...) O Congresso se revela disposto a facilitar a tramitação das matérias presidenciais (...) (Figueiredo; Limongi, 1999, p. 41-42).

${ }^{18}$ Isso não quer dizer que não haja críticas às premissas e conclusões dessa agenda de estudos legislativos do país, como, por exemplo as apontadas por Melo (2007), Reis (2007), Nunes (2011), Lucas e Samuels (2011). 
literatura sobre as novas democracias não modificou aquele que sempre foi seu consenso básico, qual seja, a governabilidade é o bem maior a ser atingido e as oposições partidárias podem ser um obstáculo à consecução desse objetivo. Para os críticos do modelo constitucional brasileiro, o governo tem dificuldades para ultrapassar a oposição legislativa, o que é negativo; para os revisionistas, a oposição parlamentar não consegue vetar o governo, o que é positivo. Para ambos, a governabilidade, enquanto preponderância da coalizão de governo, é positiva e a efetividade da oposição parlamentar é negativa.

\section{CONCLUSÃO}

A constatação de que, intencionalmente ou não, a literatura comparada sobre as novas democracias, ao privilegiar a governabilidade, privilegiou o governo em detrimento das oposições parlamentares põe em relevo a seguinte questão: qual, afinal, é o espaço institucional previsto para a atuação efetiva das oposições partidárias no Legislativo? Outra questão crucial que emerge desse debate é esta: dado que a lógica da governação envolve a interação competitiva do governo com a oposição, faz sentido supor que a preponderância do governo significa a preponderância do Executivo diante do Legislativo?

Numa lógica governativa em que as coalizões são a tônica, tudo indica que não faz sentido supor que a preponderância do Executivo seja uma ameaça à autonomia do Legislativo enquanto tal. Afinal, não há um Legislativo compactado que age em uníssono em oposição ao governo, assim como não há um Legislativo que se movimenta em bloco a favor do governo ou que se curva completamente à sua vontade. O presidencialismo de coalizão, assim como qualquer coalizão de governo em regimes parlamentaristas, impõe uma dinâmica de confronto mais ou menos tenso entre grupos partidários que ocupam o Executivo e o Legislativo simultaneamente. Dessa maneira, a assim chamada preponderância do Executivo, na verdade, é a preponderância da coalizão de governo que se impõe não diante do Poder Legislativo, mas sim perante a oposição parlamentar no Legislativo.

Percebidos dessa forma, os grupos políticos cruciais do jogo político-constitucional são o governo, de um lado, resultado da sobreposição de partidos que ocupam o Executivo com partidos que ocupam o Legislativo, e a oposição parlamentar, de outro, que ocupa apenas o Legislativo e que não sela aliança com o Presidente. Desse modo, a dominância do Executivo é, na verdade, a dominância do governo frente à oposição legislativa. O Parlamento não é ameaçado quando o Presidente exerce controle sobre o processo legislativo, pois há partidos nessa Casa representativa que agem em colaboração com o Executivo. O que está sob ameaça quando o Executivo e parcela do Legislativo têm poderes suficientes para sempre impor a sua agenda é a efetividade das oposições parlamentares. Assim, a governabilidade tão almejada pelos Presidentes e, como vimos, pela literatura especializada, pode significar a anulação da oposição no Legislativo.

Em realidade, há dois paradoxos nessa relação intrincada entre democracia, governo e oposição. O primeiro envolve duas situações. Se forem muito efetivas, as oposições parlamentares podem induzir o governo ao aumento da coesão de sua coalizão para fazer frente às investidas oposicionistas. Nesse caso, a efetividade da oposição resulta na sua posterior perda de efetividade. Por outro lado, se a efetividade da oposição parlamentar sobrepujar a coalizão de governo, corre-se o risco de um acuamento do governo e de sua paralisia. Ou seja, a oposição, nesse caso, não é uma força marginal no processo de decisão, mas um fator importante na determinação das negociações e dos resultados. O segundo paradoxo resulta da situação de baixa efetividade ou nenhuma efetividade da oposição parlamentar. Nesse caso, como considerar que há uma democracia de elevada qualidade quando o governo tem a oposição controlada e inerte? 
Esse paradoxo, por consequência, envolve a identificação do ponto ótimo da efetividade da oposição parlamentar vis-à-vis a governabilidade. Se a governabilidade for excessiva, isso dar-se-á à custa da efetividade da oposição; se a efetividade oposicionista for demasiada, isso comprometerá a efetividade do governo. Não há dúvidas de que esse é um paradoxo de difícil resolução, mas, de qualquer modo, ele aponta para o fato de que se, por um lado, a oposição não faz parte do governo, por outro, ela deve fazer parte da governação. Ou seja, não é possível avaliar a democracia sem avaliar a atuação e a efetividade das oposições partidárias parlamentares. Esse aspecto foi desconsiderado pela literatura comparada que, de modo geral, negligenciou estudos mais sistemáticos sobre as oposições partidárias (cf. Helms, 2004, 2008a, 2008b). A análise crítica desse debate evidencia, portanto, a necessidade de se estabelecer essa agenda de pesquisa, mediante o exame do comportamento das oposições, de suas prerrogativas e da sua efetividade no desempenho de suas funções constitucionais no arranjo institucional democrático.

Recebido para publicação em 24 de janeiro de 2018 Aceito em 03 de dezembro de 2020

\section{REFERÊNCIAS}

ABRANCHES, S. Presidencialismo de Coalizão: O Dilema 은 Institucional Brasileiro. Dados, v.31, n.1, p. 05-38, 1998.

ণิ ABRÚCIO, F. Os Barões da Federação: Os Governadores e Æં a Redemocratização Brasileira. São Paulo: Hucitec, 1998.

○ AMES, B. The Deadlock of Democracy in Brazil. Ann จิ Arbor: The University of Michigan Press, 2001.

งิ Electoral rules, constituency pressures, and pork I barrel: bases of voting in the Brazilian Congress. The . Journal of Politics, v. 57, n. 2, p. 324-343, 1995a.

Electoral strategy under open-list proportional

$\rightarrow$ representation. American Journal of Political Science, v.39, n. 2 , p. 406-433, $1995 \mathrm{~b}$.

AMORIM NETO, O. Cabinets and Coalitional $\geq$ Presidentialism. In: AMES, B. (Ed.), Handbook of Brazilian i Politics. New York: Routledge, 2019.
BAGEHOT, W. The English Constitution. London: Chapman and Hall, 1867.

BEZERRA, G. Oposições parlamentares no Brasil: uma análise dos incentivos institucionais e de suas práticas, 1995-2014. 2017.Tese (Doutorado em Ciência Política) - Programa de Pós-Graduação em Ciência Política da Universidade Federal do Rio Grande do Sul.

CARVALHO, N. R. E no Início eram as Bases: Geografia Política do Voto e Comportamento Legislativo no Brasil. Rio de Janeiro: Revan, 2003.

CHEIBUB, J. Presidentialism, parliamentarism, and democracy. Cambridge University Press, 2006.

CHEIBUB, J. et. al. Government Coalitions and Legislative Success under Parliamentarism and Presidentialism. British Journal of Political Science, n. 34, p. 565-587, 2004.

CHEIBUB, J.; LIMONGI, F. Democratic institutions and regime survival: Parliamentary and presidential democracies reconsidered. Annual review of political science, v. 5, n. 1, p. 151-179, 2002.

COPPEDGE, M. The dynamic diversity of Latin American party systems. Party Politics, v. 4, n. 4, p. 547-568, 1998.

DAHL, R. Poliarquia: participação e oposição. Edusp, 1997.

DANTAS, H. (Org.) Governabilidade: Para Entender a Política Brasileira. Rio de Janeiro: Fundação KonradAdenauer, 2018.

DIAMOND, L.(Ed.). Consolidating the Third Wave of Democracies. Baltimore: Johns Hopkins University Press, 1997.

DUVERGER, M. Les Partis Politiques. Paris: Librairie Armand Colin, 1951.

FIGUEIREDO, A.; LIMONGI, F. Executivo e Legislativo na Nova Ordem Constitucional. Rio de Janeiro: FGV, 1999.

Presidential power, legislative organization, and party behavior in Brazil. Comparative Politics, p. 151-170, 2000 .

Instituições Políticas e Governabilidade: Desempenho do Governo e Apoio Legislativo na Democracia Brasileira. In: MELO, C.; ALCANTARA, S. (Orgs.). A Democracia Brasileira: Balanço e Perspectivas. Belo Horizonte: UFMG, 2007, p.147-198.

A Crise Atual e o Debate Institucional. Novos Estudos Cebrap, v.36, n. 03, pp. 79-97, 2017.

FIGUEIREDO, A. Política Orçamentária no Presidencialismo de Coalizão. Rio de Janeiro: Editora FGV, 2008.

Government Coalitions in Brazilian Democracy. Brazilian Political Science Review, v. 1, n.2, p. 182-216, 2007.

FIORINA, M. An era of divided government. Political Science Quarterly, v. 107, n. 3, p. 387-410, 1992.

FOWERAKER, J. Institutional Design, Party System and Governability: Differentiating the Presidential Regimes in Latin America. British Journal of Political Science, 28, 651676, 1998.

FREEUDENREICH, J. The Formation of Cabinet Coalitions in Presidential Systems. Latin American Politics and Society, v. 58, n. 4, p. 80-102, 2016.

FREITAS, A. O Presidencialismo da Coalizão. Rio de Janeiro: Fundação Konrad-Adenauer, 2016.

GEDDES, B. Politician's dilemma: building state capacity in Latin America. Univ of California Press, 1996.

A game theoretic model of reform in Latin American democracies. American Political Science Review, v. 85, n. 2, p. 371-392, 1991. 
GIBSON, E. (Ed). Federalism and Democracy in Latin America. Baltimore: Johns Hopkins University Press, 2004.

HAGGOPIAN, F.; MAINWARING, S. (Eds.) The Third Wave of Democratization in Latin America. Cambridge: Cambridge University Press, 2005.

HELMS, L. Parliamentary Opposition in Old and New Democracies. New York: Routleged, 2008a.

Studying parliamentary opposition in old and new democracies: Issues and perspectives. The Journal of Legislative Studies, v. 14, n. 1-2, p. 6-19, 2008b.

. Five ways of institutionalizing political opposition: lessons from the advanced democracies. Government and Opposition, v. 39, n. 1, p. 22-54, 2004

HIROI, T. Governability and Accountability in Brazil: Dilemma of Coalitional Presidentialism. The Journal of Social Sciences, 75, pp. 39-59, 2013

HOCHSTETLER, K. The Fates of Presidents in PostTransition Latin America: From Democratic Breakdown to Impeachment to Presidential Breakdown. Journal of Politics in Latin America, 3/1, p. 125-141, 2011.

HUBER, J. Rationalizing Parliament: Legislative Institutions and Party Politics in France. Cambridge: Cambridge University Press, 1996.

INÁCIO, M.; RENNÓ, L. (Org.). Legislativo Brasileiro em Perspectiva Comparada. Belo Horizonte: Editora UFMG, 2009.

JONES, M. Electoral Laws and the Survivel of Presidential Democracies. Notre Dame: University of Notre Dame Press, 1995

KIM, Y. Impeachment and Presidential Politics in New Democracies. Democratization, v. 21, n. 03, p. 519-553, 2014.

KITSCHELT, H. et. al. Latin American Party Systems. Cambridge: Cambridge University Press, 2010.

KOOIMAN, J. Exploring the Concept of Governability. Journal of Comparative Policy Analysis, v. 10, n. 2, p. 171 190, 2008.

LAMEIRA, R. Por que Caem os Presidentes? Rejeição Popular, Oposição Majoritária e Impeachments no Brasil. Tese de Doutorado, Programa de Pós-Graduação em Ciência Política, UFRGS, 2019.

LEVITISKI, S.; ZIBLAT, D. How Democracies Die. New York: Crown Publishing, 2018.

LIJPHART, A. Patterns of Democracy: Government Forms and Performance in Thirty-Six Countries. New Haven: Yale University Press, 2003.

Democracies: Forms, performance, and constitutional engineering. European Journal of Political Research, v. 25, n. 1, p. 1-17, 1994.

(Ed.). Parliamentary versus presidential government. Oxford University Press, 1992

Majoritarian Versus Consensual Democracy. In: $\overline{\mathrm{BROW}} \mathrm{N}$, B. Comparative Politics: Notes and Readings, Wadsworth Publishing Company, p. 175-84, 1996.

LIJPHART, A; WAISMAN, C. (Eds.). Institutional Design in New Democracies: Eastern Europe and Latin America. New York: Westview Press, 1996.

LIMONGI, F O Poder Executivo na Constituicão de 1988. In: OLIVEN, R.; RIDENTI, M. e BRANDÃO, G. (Orgs.) A Constituição de 1988 na Vida Brasileira. São Paulo: Hucitec/Anpocs, 2008

. A democracia no Brasil: presidencialismo, coalizão partidária e processo decisório. Novos estudos-CEBRAP, $\mathrm{n}$. 76, p. $17-41,2006$

LIMONGI, F; FIGUEIREDO, A. Política Orçamentária no Presidencialismo de Coalizão. Rio de Janeiro: Editora FGV, 2008.
LINZ, J. Presidential or Parliamentary Democracy: Does it Make a Difference?. In: - VALENZUELA, A. (Eds.) The Failure of Presidential Democracy, v. 1. Baltimore: Johns Hopkins University Press, 1994.

The Perils of Presidentialism. Journal of Democracy, v.1, n.1, p. 51-69, 1990a.

The Virtues of Paliamentarism. Journal of Democracy, v.1, n.4, p. 84-91, 1990b.

LINZ, J.; VALENZUELA, A. The Failure of Presidential Democracy: Comparative Perspectives. Baltimore: Johns Hopkins University Press, 1994a.

The Failure of Presidential Democracy: The Case of Latin America. Baltimore: Johns Hopkins University Press, 1994b.

LINZ, J. Parties in Contemporary Democracies: Problems and Paradoxes. In: GUNTHER, R.; MONTERO, J.; LINZ, J. (Ed.). Political parties: old concepts and new challenges, Oxford, p. 291-317, 2002.

LINZ, J.; STEPAN, A. Problems of Democratic Transition and Consolidation. Baltimore: Johns Hopkins University Press, 1993.

LLANOS, M.; MARSTEINTREDET, L. (Ed.). Presidential breakdowns in Latin America: Causes and outcomes of executive instability in developing democracies. Springer, 2010.

LUCAS, K.; SAMUELS, D. A coerência ideológica do sistema partidário brasileiro, 1990-2009. In: ZUCCO JR., C.; POWER, T. O Congresso por ele mesmo: autopercepcões da classe política brasileira. Editora UFMG: Belo Horizonte. 2011, p.61-104

LUZ, J.; AFLALO, H.; DUTRA, A. B. A Relação ExecutivoLegislativo Revisitada: A Governabilidade da Coalizão no Brasil. In: DANTAS, H. (Org.), Governabilidade: Para Entender a Política Brasileira. Rio de Janeiro: KonradAdenauer Stiftung, 2018, p.45-62.

MAINWARING, S. Rethinking party systems in the third wave of democratization: the case of Brazil. Stanford University Press, 1999.

Multipartism, robust federalism, and presidentialism in Brazil. Presidentialism and democracy in Latin America, p. 55-109, 1997.

Brazil: Weak Parties, Feckless Democracy. In: ; SCULLY, T. Building Democratic Institutions: Party Systems in Latin America. Stanford: Stanford University Press, 1995

Presidentialism, multipartism, and democracy: The difficult combination. Comparative political studies, v. 26, n. 2, p. 198-228, 1993.

Presidentialism in Latin America. Latin American

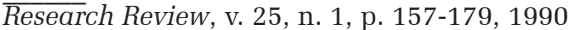

MAINWARING, S; SHUGART, M. (Ed.). Presidentialism and democracy in Latin America. Cambridge University Press, 1997a.

Juan Linz, Presidentialism, and Democracy: A Critical Appraisal. Comparative Politics, v. 29, n. 4, p. 449$471,1997 \mathrm{~b}$

MAINWARING, S.; PÉREZ-LIÑÁN, A. Party discipline in the Brazilian constitutional congress. Legislative studies quarterly, p. 453-483, 1997.

MAINWARING, S; SCULLY, T. (Ed.). Building democratic institutions: Party systems in Latin America. Stanford, CA: Stanford University Press, 1995.

MARSTEINTREDET, L. Explaining variation of executive instability in presidential regimes: Presidential interruptions in Latin America. International Political Science Review, v. 35, n.2, p. 173-194, 2014. 
MARSTEINTREDET, L; BERNTZEN, E. Reducing the Perils of Presidentialism in Latin America through Presidential interruptions. Comparative Politics, v. 41, n.1, p. 83-101, 2008.

MAYHEW, D. Divided we govern: Party control, lawmaking and investigations, 1946-2002. Yale University Press, 2005. Press, 1974.

Congress: The electoral connection. Yale University

MEIRELES, F. Oversized Government Coalitions in Latin America. Brazilian Political Science Review, v. 10, n. 3, 2016.

MELO, C. Nem tanto ao mar, nem tanto a terra. In:

SAÉZ, M.(orgs.). A Democracia Brasileira: balanço e perspectivas para o século 21. Belo Horizonte: Editora UFMG, 2007, p.267-302.

MELO, C.; SANTOS, M. Y La nave va: Brasil bajo Dilma Rousseff. Revista de Ciencia Política (Santiago), v. 33, n. 1, p. 55-81, 2013.

MELO, M.; PEREIRA, C. Making Brazil work: checking the president in a multiparty system. Springer, 2013.

MENEGUELLO, R. Partidos e governos no Brasil contemporâneo:(1985-1997). Paz e Terra, 1998.

MIRANDA, G. A influência da dinâmica eleitoral sobre o comportamento dos partidos na Câmara dos Deputados e no Senado Federal. Dados, v. 52, n. 4, p. 911-960, 2009.

. A delegação aos líderes partidários na Câmara dos Deputados e no Senado Federal. Revista de Sociologia e Política, v. 18, n. 37, p. 201-225, 2010.

MOE, T. Political institutions: The neglected side of the story. Journal of Law, Economics, \& Organization, v. 6, p. 213-253, 1990.

MORGENSTERN, S.; NACIF, B. (Eds.) Legislative Politics in Latin America. Cambridge: Cambridge University Press, 2002.

MORGENSTERN, S.; NEGRI, J.; PÉREZ-LIÑÁN, A. Parliamentary opposition in non-parliamentary regimes: Latin America. The Journal of Legislative Studies, v. 14, n. 1-2, p. 160-189, 2008.

MOUNK, Y. The People Vs. Democracy. Cambridge: Harvard University Press, 2018.

NUNES, E. Fragmentação de Interesses e Morosidade no Parlamento. In: MOISẺS, J. (org.). O papel do Congresso Nacional no presidencialismo de coalizão. Rio de Janeiro, Konrad-Adenauer-Stiftung, 2011, p.30-42.

O'DONNELL, G. Transitions, continuities, and paradoxes. ค In: MAINWARING, S.; (eds.), Issues in Democratic o Consolidation: The New South American Democracies in N Comparative Perspective. Notre Dame, University of Notre Æే Dame Press, 1992, p. 17-56.

\&े ORDESHOOK, P.; SHVETSOVA, O. Ethnic heterogeneity, o district magnitude, and the number of parties. American i journal of political science, p. 100-123, 1994.

I PALERMO, V. Como se Governa o Brasil? O Debate sobre $\dot{2}$ as Instituições Políticas e Gestão de Governo. Dados, v. 43, คे n.3, p.521-557, 2000.

$>$ PAPPAS, T. Populist in Power. Journal of Democracy, v. 30, if n. 2, p. 70-80, 2019.

PEREIRA, C. All the President's Men and Women: Coaltion 3 Manegement Strategies and Governing Costs in Multiparty œ Presidency. Presidential Studies Quarterly, v. 46, n.3, p. 550-568, 2016.

Oु PEREIRA, C.; RENNO, L. O que é que o reeleito tem? O retorno: o esboço de uma teoria da reeleição no Brasil. Revista de Economia Política, v. 27, p. 664-683, 2007. O que é que o Reeleito tem? Dinâmicas Político-
Institucionais Locais e Nacionais nas Eleições de 1998 para a Câmara dos Deputados. Dados, v. 44, n. 2, pp. 323362, 2001.

PERES, P. O governismo na política brasileira. In: TEIXEIRA, Marco Antonio Carvalho; DANTAS, Humberto; TOLEDO, José Roberto de. Análise política e jornalismo de dados. Rio de Janeiro: FGV, 2014, p. 37-56.

PERES, P. Comportamento ou instituições? A evolução histórica do neo-institucionalismo da ciência política. Revista Brasileira de Ciências Sociais, v. 23, n. 68, p. 53-71, 2008.

PERES, P.; CARVALHO, Ernani. Religando as arenas institucionais: uma proposta de abordagens multidimensionais nos estudos legislativos. Revista de Sociologia e Política, v. 20, n. 43, p. 81-106, 2012.

PERES, P.; BEZERRA, G. Oposição Parlamentar: Conceito e Funções. Lua Nova: Revista de Cultura e Política, v. 110, p. 247-298, 2020 .

PÉREZ-LIÑAN, A. Impeachment or Backsliding? Threats to Democracy in the Twenty-First Century. Revista Brasileira de Ciência Política, v. 33, n. 98, p. 1-15, 2018.

Instituciones, Coaliciones Callejeras e Inestabilidad Política: Perspectivas Teóricas sobre las Crisis Presidenciales. América Latina Hoy, n. 49, p. 105126, 2008.

Presidential Impeachment and the New Political Instability in LatinAmerica. Cambridge: Cambridge University Press, 2007.

POWER, T. Optimism, pessimism, and coalitional presidentialism: Debating the institutional design of Brazilian democracy. Bulletin of Latin American Research, v. 29, n. 1, p. 18-33, 2010.

Compulsory for whom? Mandatory voting and electoral participation in Brazil, 1986-2006. Journal of Politics in Latin America, v.1, n.1, p. 97-122, 2009.

PRZEWORSKI, A. et al. Democracy and Development: Political Institutions and Material Well-Being in the World (1950-1990). Cambridge: Cambridge University Press, 2000 .

REIS, B. O presidencialismo de coalizão sob pressão: da formação de maiorias democráticas à formação democrática de maiorias. Revista Plenarium, v. 4, n. 4, p. 80-103, 2007.

RIGGS, F. W. The Survival of Presidentialism in America: Para-Constitutional Practices. International Political Science Review, v. 9, n.4, p. 247-278, 1988.

SAMUELS, D. Ambition, federalism, and legislative politics in Brazil. Cambridge University Press, 2003.

SANI, G.; SARTORI, G. Polarization, fragmentation and competition in Western democracies. Western European party systems, p. 307-340, 1983.

SANTOS, F. O Poder Legislativo no Presidencialismo de Coalizão. Belo Horizonte: Editora UFMG, 2003.

SANTOS, M.; PERLIN, G. (Orgs.). Presidencialismo de Coalizão em Movimento. Brasília: Edições Câmara, 2019.

SANTOS, W. 64: Anatomia da Crise. São Paulo: Vértice, 1986.

SARTORI, G.Comparative constitutional engineering: an inquiry into structures, incentives, and outcomes. NYU Press, 1997.

SHUGART, M. The inverse relationship between party strength and executive strength: a theory of politicians' constitutional choices. British Journal of Political Science, v. 28, n. 1, p. 1-29, 1998.

SHUGART, M.; CAREY, J. Presidents and assemblies: Constitutional design and electoral dynamics. Cambridge University Press, 1992. 
STEPAN, A.; SKACH, C. Constitutional frameworks and democratic consolidation: Parliamentarianism versus presidentialism. World politics, v. 46, n. 1, p. 1-22, 1993.

STROM, K. Minority Government and Majority Rule. Cambridge: Cambridge University Press, 1990.

TSEBELIS, G. Veto Players: How Political Institutions Work. Princeton: Princeton University Press, 2002.

. Decision making in political systems: Veto players in presidentialism, parliamentarism, multicameralism and multipartyism. British journal of political science, $\mathrm{v}$. 25, n. 3, p. 289-325, 1995.

URBINATI, N. Me the People: How Populism Transforms Democracy. Cambridge: Harvard University Press, 2019.

VALENZUELA, A. Latin American presidencies interrupted. Journal of Democracy, v. 15, n. 4, p. 5-19, 2004.
. Latin America: Presidentialism in Crisis. Journal of Democracy, v. 4, n. 4, p. 3-16, 1993.

VERNEY, D. The Analysis of Political Systems. London: Routledge, 1959.

WEAVER, R. A New Look at Federalism: Electoral Rules and Governability. Journal of Democracy, v. 13, n. 2, p. 111-125, 2002.

WHITEHEAD, L. (Ed.). The international dimensions of democratization: Europe and the Americas. Oxford University Press, 1996.

ZELAZNIK, J. The Building of Coalitions in the Presidential Systems of Latin America: An Inquiry into the Political Conditions of Governability. PhD Dissertation, University of Essex, 2001. 


\section{PRESIDENTIALISM, GOVERNABILITY AND PARLIAMENTARY OPPOSITIONS: a critical analysis of the comparative literature}

\author{
Paulo Sérgio Peres \\ Gabriella Maria Lima Bezerra
}

\author{
PRÉSIDENTIALISME, GOUVERNABILITÉ ET \\ OPPOSITIONS PARLEMENTAIRES: une analyse \\ critique de la littérature comparée \\ Paulo Sérgio Peres \\ Gabriella Maria Lima Bezerra
}

Our proposal in this article is to analyze the debate on presidentialism, having as central the theme of governability and its relation with the performance of party oppositions in the legislative arena. We argue that the concern with the consolidation of recent democracies has led analysts to privilege governance over the effectiveness of parliamentary opposition. In this way, the evolution of studies and debates about the most appropriate constitutional designs for democratic consolidation has resulted, on the one hand, in the conception that, if effective, parliamentary oppositions can harm the consolidation of new democracies and, on the other, in a lack of empirical research on their prerogatives and behavior. We defend the need to overcome this normative bias and the development of an investigation agenda on its strategic performance, after all, parliamentary oppositions are indispensable actors in the democratic regime.

KEYwORDS: Parliamentary oppositions. Presidentialism. Governance. Executive and Legislative.
Notre proposition dans cet article est d'analyser le débat sur le présidentialisme, ayant comme central le thème de la gouvernabilité et sa relation avec la performance des oppositions dans l'arène législative. Nous soutenons que le souci de la consolidation des démocraties récentes a conduit les analystes à privilégier la gouvernance sur l'efficacité de l'opposition parlementaire. De cette manière, l'évolution des études et des débats sur les conceptions constitutionnelles les plus appropriées pour la consolidation démocratique a abouti, d'une part, à l'idée que, si elles sont efficaces, les oppositions parlementaires peuvent nuire à la consolidation des nouvelles démocraties et, d'autre part, à une manque de recherche empirique sur leurs prérogatives et leurs comportements. Nous défendons la nécessité de surmonter ce biais normatif et le développement d'un programme d'enquête sur ses performances stratégiques, après tout, les oppositions parlementaires sont des acteurs indispensables du régime démocratique.

Mots-Clès: Les oppositions parlementaires. Présidentialisme. La gouvernance. Exécutif et législatif.

Paulo Peres - Doutor em Ciência Política pela Universidade de São Paulo. Professor adjunto do Departamento de Ciência Política e pesquisador e professor permanente do Programa de Pós-Graduação em Ciência Política da Universidade Federal do Rio Grande do Sul. Coordenador do Núcleo de Estudos sobre Partidos e Democracia - NEPD/UFRGS, desenvolvendo pesquisas na área de Ciência Política, atuando principalmente nos seguintes temas: instituições políticas brasileiras, partidos e sistemas partidários, teoria democrática e história, epistemologia e metodologia da Ciência Política. Publicações recentes: PERES, P. S.; BEZERRA, G. Oposição Parlamentar: Conceito e Funções. Lua Nova: Revista de Cultura e Política, v. 110, p. 247-298, 2020; CORREA, C.; PERES, P. S. Governabilidade e Comissões: Três Gerações de Estudos Legislativos no Brasil. In: Dantas, Humberto. (Org.). Governabilidade: Para Entender a Política Brasileira. $1^{\mathrm{a} e d . R i o ~ d e ~ J a n e i r o: ~ K o n r a d-A d e n a u e r ~ S t i f t u n g, ~ 2019, ~ v . ~ 1, ~ p . ~ 63-86 ; ~}$ LENINE, E.; MORSCHBACHER, M.; PERES, P. S. Methodological. International Political Science Review, p. 019251211875559-689, 2018.

Gabriella Bezerra - Doutora em Ciência Política pela Universidade Federal do Rio Grande do Sul. Professora do Departamento de Ciências Sociais da Universidade Federal Rural de Pernambuco - UFRPE, Integra o Laboratório de Estudos sobre Política, Eleições e Mídia da Universidade Federal do Ceará LEPEM/UFC e o Núcleo de Estudos sobre Partidos e Democracia- NEPD/UFRGS, desenvolvendo pesquisas na área de Ciência Política, atuando principalmente nos seguintes temas: teoria democrática, instituições políticas comparadas e estudos legislativos. Publicações recentes: PERES, Paulo S.; BEZERRA, Gabriella. M. L. Oposição Parlamentar: Conceito E Funções. Lua Nova: Revista de Cultura e Política, v. 110, p. 247298, 2020; LOPES, Monalisa S.; PAIVA, Graziella. M.; BEZERRA, Gabriella M. L. 2018, a batalha final?: Lava Jato e Bolsonaro numa campanha anticorrupção e antissistema. CIVITAS: REVISTA DE CIÊNCIAS SOCIAIS (no prelo), edição de dezembro de 2020. 